\title{
PENGGUNAAN METODE PEMBERIAN TUGAS TERBIMBING BERBASIS MULTIMEDIA INTERAKTIF DALAM MATA KULIAH TEORI GRAF UNTUK MENINGKATKAN PRESTASI BELAJAR MAHASISWA TAHUN AKADEMIK 2011/2012
}

\author{
${ }^{1}$ Reza Kusuma Setyansah, ${ }^{2}$ Ika Krisdiana \\ ${ }^{1}$ Dosen Prodi Matematika IKIP PGRI Madiun \\ ${ }^{2}$ Dosen Prodi Matematika IKIP PGRI Madiun
}

\begin{abstract}
Abstrak. Penelitian ini bertujuan untuk melihat dampak perkembangan aktivitas belajar mahasiswa berdasarkan pengembangan penggunaan media pembelajaran interaktif berupa power point pada perkuliahan teory graf mahasiswa yang selanjutnya diharapkan akan membantu meningkatkan prestasi belajar mahasiswa.

Penelitian ini merupakan Penelitian Tindakan Kelas (PTK) yang terdiri dari tiga siklus. Pada masing-masing siklus memiliki empat tahap yaitu, tahap perencanaan, tahap pelaksanaan, tahap pengamatan dan tahap refleksi. Subjek penelitian ini adalah mahasiswa semester genap (kelas VI-A) tahun akademik 2011/2012 yang berjumlah 37 orang. Adapun teknik pengumpulan data dilakukan dengan wawancara, observasi langsung dan tes. Analisa data yang dilakukan adalah analisis diskriptif kualitatif.

Dari hasil penelitian 37 orang mahasiswa pada siklus I diperoleh banyaknya mahasiswa yang tuntas adalah 13,51\% dan 86,49\% mahasiswa yang tidak tuntas.Pada siklus II diperoleh banyaknya mahasiswa yang tuntas adalah $27,03 \%$ dan $72,97 \%$ mahasiswa yang tidak tuntas. Pada siklus III diperoleh banyaknya mahasiswa yang tuntas adalah72,97\% dan 27,03\% mahasiswa yang tidak tuntas. Hal ini menunjukkan adanya peningkatan yang cukup berarti. Pada perlakuan Siklus II dan siklus III selain terdapat peningkatan prestasi, penerapan metode pemberian tugas terbimbing memiliki pengaruh yang cukup berarti dalam meningkatkan kemandirian belajar mahasiswa.
\end{abstract}

Keywords: Teori Graf, Media Pembelajaran, Prestasi Belajar.

\section{PENDAHULUAN}

Pendidikan merupakan
pemegang peranan penting dalam
tercapainya suatu tujuan pembangunan
nasional. Dalam mengapresiasikan suatu
tujuan tersebut dibutuhkan dorongan
karakter masyarakat adil, jujur dan
makmur, merata secara moral, spirituil
dan materiil berdasarkan pancasila di
dalam Negara Kesatuan Republik
Indonesia yang merdeka, bersatu,
berdaulat dalam suasana kehidupan
bangsa yang aman, tentram, tertib dan
dinamis serta dalam lingkungan
pergaulan dunia yang merdeka,
bersahabat, tertib dan damai.
Republik Indonesia Nomor 19 Tahun
2005 tentang Standar Nasional
Pendidikan dinyatakan pada hakekatnya

pendidikan dalam konteks pembangunan nasional mempunyai fungsi (1) pemersatu bangsa, (2) penyamaan kesempatan, dan (3) pembangunan potensi diri. Pendidikan diharapkan dapat memperkuat keutuhan bangsa memberi kesempatan yang sama bagi setiap warga negara untuk berprestasi dalam pembangunan,dan memungkinkan setiap warga negara untuk mengembangkan potensi yang dimilikinya secara optimal.

Sementara itu, UndangUndang Republik Indonesia Nomor 20 Tahun 2003 tentang Sistem Pendidikan Nasional merupakan dasar hukum penyelenggaraan dan reformasi sistem pendidikan nasional. Undang-Undang tersebut memuat visi, misi, fungsi dan tujuan pendidikan nasional serta strategi pembangunan pendidikan nasional, untuk memujudkan pendidikan yang 
bermutu, relevan dengan kebutuhan masyarakat, dan berdaya saing dalam kehidupan global.

Visi Pendidikan Nasional adalah mewujudkan sistem pendidikan sebagai pranata sosial yang kuat dan berwibawa untuk memberdayakan semua warga Negara Indonesia, agar berkembang menjadi manusia yang berkualitas, sehingga mampu berproduktif menjawab tantangan zaman yang selalu berubah.

Misi Pendidikan nasional yaitu (1) mengupayakan perluasan dan pemerataan kesempatan memperoleh pendidikan yang bermutu bagi seluruh rakyat Indonesia, (2) meningkatkan mutu pendidikan yang memiliki daya saing di tingkat nasional, regional, dan internasional, (3) meningkatkan relevansi pendidikan dengan kebutuhan masyarakat dan tantangan global, (4) membantu dan memfasilitasi pengembangan potensi anak bangsa secara utuh. sejak usia dini sampai akhir hayat dalam rangka mewujudkan masyarakat belajar. (5) meningkatkan kesiapan masukan dan kualitas proses pendidikan untuk mengoptimalkan pembentukan kepribadian yang bermoral. (6) meningkatkan keprofesionalan dan akuntabilitas lembaga pendidikan sebagai pusat pembudayaan ilmu pengetahuan ketrampilan pengalaman sikap, dan nilai berdasarkan standar yang bersifat nasional dan global (7) mendorong peran serta masyarakat dalam menyelenggarakan pendidikan berdasarkan prinsip otonomi dalam konteks Negara Kesatuan Republik Indonesia. Terkait dengan visi dan misi pendidikan nasional di atas, reformasi pendidikan meliputi hal-hal berikut: Pertama penyelenggaraan pendidikan dinyatakan sebagai suatu proses pembudayaan dan pemberdayaan peserta didik yang berlangsung sepanjang hayat dimana dalam proses tersebut harus ada pendidik yang mampu memberikan keteladanan dan mampu membangun semangat belajar yang tinggi, serta mampu mengembangkan potensi dan kreatifitas peserta didik. Kedua adanya perubahan pandangan tentang peran manusia dari paradigma manusia sebagai sumber daya pembangunan, menjadi paradigma manusia sebagai subjek pembangunan secara utuh.

\begin{tabular}{llr}
\multicolumn{2}{c}{ Pendidikan } & nasional \\
mempunyai & fungsi & dalam \\
mengembangkan & kemampuan & dan
\end{tabular} membentuk watak serta peradaban bangsa yang bermartabat dalam rangka mencerdaskan kehidupan bangsa. Bertujuan untuk mengembangkan potensi peserta didik agar menjadi manusia yang beriman, dan bertaqwa kepada Tuhan Yang Maha Esa, beraklak mulia, sehat, berilmu, cakap, kreatif, mandiri dan menjadi Warga Negara yang demokratis, serta bertanggung jawab.

Untuk mengemban fungsi tersebut pemerintah menyelenggarakan suatu sistem pendidikan nasional sebagaimana tercantum dalam UndangUndang Republik Indonesia Nomor 20 tahun 2003 tentang Sistem Pendidikan Nasional dan Peraturan Pemerintah Indonesia nomor : 19 tahun 2005 tentang Standar Nasional Pendidikan mengamanatkan tersusunnya kurikulum tingkat satuan pendidikan (KTSP) pada jenjang pendidikan dasar dan menengah dan mengacu kepada permendiknas Nomor 22 Tahun 2006 tetang standar isi, serta berpedoman pada panduan yang disusun oleh Badan Standart Nasional Pendidikan (BSNP).

Pendidikan di Indonesia saat ini masih jauh tertinggal jika dibandingkan dengan pendidikan di negara-negara tetangga, seperti Singapura, Thailand dan Malaysia. Pendidikan dalam Sistem Pendidikan Nasional adalah usaha sadar untuk menyiapkan peserta didik melalui kegiatan bimbingan, pengajaran atau latihan. Hal yang perlu dicermati dalam makna pendidikan adalah apa yang disebut usaha sadar yang semestinya melekat pada setiap proses pendidikan termasuk proses kegiatan belajar mengajar. 
Rendahnya mutu pendidikan di Indonesia disebabkan adanya beberapa faktor, salah satunya adalah kurang profesionalnya dosen dalam mengajar. Pada umumnya dosen dalam melaksanakan kegiatan pembelajaran masih menggunakan metode ceramah secara dominan sehingga hasil pembelajaran kurang memuaskan karena metode ceramah dianggap paling mudah dilaksanakan dan efisien, tanpa persiapanpun dapat dilaksanakan..

Dari hasil pengamatan dan pengalaman mengajar, peneliti dapat menunjukkan bahwa penggunaan metode ceramah saja dapat menyulitkan pemahaman peserta didik pada konsepkonsep yang diajarkan. Bahkan peserta didik sering tidak memperhatikan pada materi pelajaran, padahal dosen menghendaki agar peserta didik dapat menyerap pelajaran yang disampaikan semaksimal mungkin.

Pada dasarnya kemampuan peserta didik untuk menangkap isi mata kuliah tidak hanya terbatas pada kemampuan mendengar saja, tetapi lebih banyak terkait dengan kemampuan visual dan ketrampilan motorik, yang semuanya saling berkaitan.

Untuk meningkatkan hasil belajar peserta didik, peneliti berupaya memperbaiki strategi pembelajaran dengan menggunakan metode pemberian tugas. Dengan metode pemberian tugas ini diharapkan akan menambah daya tarik peserta didik terhadap materi baru dalam perkuliahan yang akan diterima oleh peserta didik dan dapat meningkatkan prestasi belajarnya.

Harapan peneliti dengan adanya strategi pembelajaran dengan metode pemberian tugas terbimbing akan memberikan dampak yang positif dalam perkembangan pemahaman peserta didik yang umumnya apabila menerima materi perkuliahan secara langsung khususnya pada mata kuliah teori graf yang terdiri dari beberapa definisi dan pola pengembangan berpikir berdasarkan kasus-kasusnya akan sulit menerima hal tersebut. Hal ini akan lebih mudah dipahami dan terima oleh peserta didik terhadap materi-materi perkuliahan teori graf khususnya dengan strategi pembelajaran dengan metode pemberian tugas terbimbing.

Secara umum, manfaat metode pemberian tugas terbimbing dalam proses pembelajaran adalah melatih peserta didik untuk belajar mandiri dengan beberapa mentoring dari dosen terhadap beberapa definisi dan kasuskasus dalam materi perkuliahan teori graf, sehingga kegiatan pembelajaran akan lebih efektif dan efisien.

Perkembangan ilmu pengetahuan dan teknologi dewasa ini semakin pesat sehingga mengakibatkan banyaknya perubahan di berbagai bidang, salah satu diantaranya yaitu pada bidang pendidikan. Pendidikan merupakan salah satu hal penting bagi manusia, karena menyangkut kelangsungan hidup manusia dan tingkat kecerdasan bangsa. Oleh karena itu keberadaan teknologi tentu saja sangat diharapkan akan dapat membantu dalam peningkatan kualitas pendidikan itu sendiri.

Upaya peningkatan kualitas pendidikan merupakan pengemban utama di dalam peningkatan kualitas sumberdaya manusia untuk menjadi pribadi yang kreatif dan mandiri. Terciptanya sumber daya manusia yang berkualitas ini diawali dari hadirnya lulusan yang bermutu. Di dalam mewujudkan mutu lulusan dari setiap institusi atau lembaga pendidikan, dapat diupayakan melalui proses pembelajaran yang dilaksanakan. Pelaksanaan pembelajaran tidak terlepas dari komponen-komponen yang harus dikembangkan pengajar, meliputi tujuan, materi, strategi pembelajaran termasuk didalamnya model, metode dan media pembelajaran serta evaluasi hasil belajar.

Selain daripada itu, hasil belajar yang harus dicapai bukan hanya sekedar tahu, menguasai ilmu dan menghafal semua teori yang dihasilkan orang lain, tetapi belajar merupakan proses berpikir. Namun dalam realita proses 
pembelajaran, seorang dosen masih menggunakan metode yang monoton dan kurang sesuai dengan materi yang diajarkan dan karakteristik mahasiswa. Pembelajaran yang demikian akan sangat membosankan bagi mahasiswa sehingga motivasi belajar mereka akan menjadi semakin rendah. Akibat yang lebih jauh adalah mahasiswa akan malas untuk belajar dan kemampuan mereka tidak akan tergali secara maksimal.

Salah satu ilmu yang saat ini senantiasa selalu dikembangkan adalah matematika. Namun, perkembangan pembelajaran matematika di lembaga pendidikan, ternyata belum sesuai dengan apa yang diharapkan. Di mana, selain prestasi mahasiswa yang masih rendah, tingkat kreatif dan produktif mahasiswa juga tergolong masih rendah. Hal ini terlihat dari sebagian mahasiswa masih belum mampu mengaplikasikan ilmu pengetahuan yang diperoleh pada kehidupan nyata.

Berdasarkan realita yang ada, ternyata memang tidak semua mahasiswa mampu menggali kreatif dan produktifnya dengan baik, artinya sampai saat ini kemampuan mahasiswa dalam hal tersebut masih menjadi masalah bagi sebagian mereka. Sebagian mahasiswa masih kesulitan dalam mengaplikasikan teori dalam matematika pada permasalahan nyata. Hal tersebut juga didukung dengan sangat minimnya kreativitas mahasiswa dalam menyelesaikan permasalahanpermasalahan yang terkait dengan matematika. Akibatnya, tentu saja akan berdampak pada rendahnya prestasi belajar mereka.

Salah satu cabang interdisiplin dari matematika yang dapat dijadikan sebagai salah satu alternatif melatihkan kreativitas dan produktivitas bagi mahasiswa adalah riset operasi, satu diantaranya yaitu pada materi program linear. Pada materi tersebut, mahasiswa dapat dilatih untuk lebih kreatif dan produktif dalam mengaplikasikan ilmu yang diperoleh pada keadaan nyata.

Berkaitan dengan upaya melatihkan kreatif dan produktif mahasiswa, tentu saja dosen sebaiknya juga mampu memilih model pembelajaran yang tepat, artinya efektif dan menarik. Menurut Widiyanto (2008: 2), Model pembelajaran matematika yang efektif dan menarik adalah model pembelajaran yang memiliki nilai relevansi dengan pencapaian daya matematika, memberi peluang untuk bangkitnya kreativitas, mampu mengembangkan suasana belajar mandiri dan sejauh mungkin memanfaatkan momentum kemajuan teknologi khususnya fungsi teknologi informasi. Mengacu pada pendapat tersebut, maka dalam penelitian ini akan digunakan model pembelajaran yang lebih menitikberatkan pada keterlibatkan mahasiswa dalam kegiatan pembelajarannya, serta memanfaatkan media website. Media website akan digunakan sebagai sarana untuk menuangkan hasil akhir kerja mahasiswa selama proses pembelajaran, dengan harapan mahasiswa yang lain dapat saling berbagi informasi utamanya pada mata kuliah riset operasi.

Adapun tujuan dalam penelitian ini untuk mengetahui: 1) Untuk mengetahui apakah model pembelajaran yang diterapkan dosen berpengaruh terhadap tingkat kreativitas dan produktivitas mahasiswa. 2) Untuk mengetahui apakah model pembelajaran yang berorientasi pada pengembangan kreativitas dan produktivitas mahasiswa mampu membantu meningkatkan prestasi belajar mahasiswa.

\section{METODE PENELITIAN}

Dalam prosedur penelitian ini terdiri atas tiga siklus, yang masingmasing siklus meliputi; perencanaan, pelaksanaan tindakan, observasi dan evaluasi refleksi.

Siklus I (Perencanaan), Pengumpulan masalah, Mengidentifikasi masalah yang dihadapi mahasiswa dan memecahkannya Menyusun rencana pembelajaran, Menyusun instrumen pembelajaran, alat observasi, alat evaluasi Menyiapkan media 
pembelajaran. (Pelaksanaan Kegiatan), meliputi Mahasiswa dikelompokkan menjadi lima kelompok, Tiap kelompok diberi tugas dengan lembar kerja mahasiswa, Mahasiswa mendiskusikan tugas yang diberikan oleh dosen, Masing-masing kelompok melaporkan hasil diskusi di depan kelas, Dosen mengevaluasi dan meluruskan hasil diskusi tentang materi perkuliahan teori graf, Dosen memberi postes/essay pada akhir materi untuk mengetahui hasil pembelajaran. (Observasi), mengkaji hasil proses belajar kemampuan awal mahasiswa. Hasil pengamatan dosen dalam pelaksanaan kegiatan ini terlihat mahasiswa begitu nyaman dan konsentrasi dalam mengerjakan lembar tugas pada akhir kegiatan mahasiswa diajak membahas pekerjaannya, apabila hasil pekerjaan mahasiswa baik dengan rata-rata mencapai $75 \%$ berarti penelitian berhasil. (Evaluasi-Refleksi) Berdasarkan hasil observasi pada siklus pertama peneliti secara kolaboratif bersama dosen dan teman sejawat mengadakan evaluasi dan refleksi pelaksanaan pembelajaran, dengan demikian peneliti dapat mengambil kesimpulan-kesimpulan yang dapat digunakan untuk bahan pertimbangan pelaksanaan perbaikan pada siklus ke 2 dan berlanjut terhadap penerapan siklus 3.

Siklus II (Perencanaan) Identifikasi masalah, Menyiapkan rencana pembelajaran, Menyiapkan lembar evaluasi dan observasi, Menyempurnakan skenario pembelajaran dengan mengoptimalkan penggunaan metode pemberian tugas dan latihan. (Pelaksanaan Kegiatan), Berdasarkan pelaksanaan siklus pertama, pengajar mengadakan perbaikan dengan menerapkan metode pemberian tugas berupa soal-soal tes, dimana tugas yang diberikan hendaknya jelas, sehingga tidak menyulitkan mahasiswa, Memberi waktu yang cukup untuk menyelesaikan tugas, Tugas yang menarik dapat mendorong mahasiswa untuk menyelesaikannya. (Observasi), mengkaji hasil pada siklus pertama.
Hasil pengamatan dosen dalam pelaksanaan kegiatan ini terlihat mahasiswa begitu nyaman dan konsentrasi dalam mengerjakan lembar tugas pada akhir kegiatan mahasiswa diajak membahas pekerjaannya, apabila hasil pekerjaan mahasiswa baik dengan rata-rata mencapai $75 \%$ berarti penelitian berhasil. (Evaluasi-Refleksi) Terbukti keberhasilan dalam melaksanakan perbaikan pembelajaran melalui penelitian dengan menggunakan metode yang tepat, dapat mengatasi masalah yaitu rendahnya prestasi belajar peserta didik dalam menerima materi pelajaran yang sudah diberikan oleh dosen. Sehingga hasil nilai tes siswa dapat memenuhi standart nilai yang sudah ditentukan.

Kegiatan merancang dan melaksanakan perbaikan pembelajaran dengan penerapan penelitian tindakan kelas dapat digambarkan dalam bentuk diagram berikut :

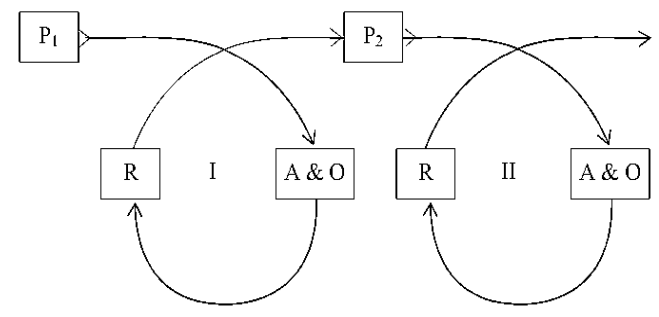

Gambar 1.

Siklus Action Research Class dalam Perbaikan Pembelajaran.

Keterangan :

$\mathbf{P}_{\mathbf{1}} \quad$ : Perencanaan ke 1

A \& O : Pelaksanaan dan Observasi

$\mathbf{P}_{\mathbf{2}} \quad$ : Perencanaan ke 2

R : Refleksi dan evaluasi

Prosentase ketuntasan belajar dikatakan berhasil jika memenuhi ketuntasan belajar $\geq 65$. Sedangkan prosentase ketuntasan belajar tidak berhasil jika ketuntasan belajar siswa < 65. 
Kualifikasi hasil ketuntasan prestasi belajar mahasiswa sesuai dengan tabel berikut:

Tabel 1. Persentase Skor Ketuntasan

\begin{tabular}{ccc}
\hline No & $\begin{array}{c}\text { Rentang } \\
\text { persentase skor } \\
\text { yang diperoleh }\end{array}$ & Kualifikasi \\
\hline 1 & $85 \%-100 \%$ & Sangat Baik \\
2 & $65 \%-85 \%$ & Baik \\
3 & $45 \%-65 \%$ & Cukup \\
4 & $25 \%-45 \%$ & Kurang \\
5 & $<25 \%$ & Sangat \\
& & Kurang \\
\hline
\end{tabular}

Respons mahasiswa dikatakan tuntas jika persentase prestasi belajar mahasiswa yang diperoleh termasuk dalam kualifikasi baik/sangat baik. Apabila hasil pekerjaan mahasiswa baik/sangat baik dengan rata-rata mencapai $75 \%$ berarti penelitian berhasil.

Berdasarkan hasil penelitian dari beberapa siklus yang telah dilaksanakan oleh peneliti, dapat dirangkum rekapitulasi ketuntasan hasil belajar mahasiswa sebagai berikut:

Tabel 2. Rekapitulasi Hasil Evaluasi pada Masing-masing Siklus

\begin{tabular}{ccc}
\hline Siklus & Tuntas & Tidak Tuntas \\
\hline I & $27 \%$ & $73 \%$ \\
II & $47 \%$ & $53 \%$ \\
III & $77 \%$ & $23 \%$ \\
Siklus & Tuntas & Tidak Tuntas \\
\hline
\end{tabular}

Secara grafik, hasil rekapitulasi di atas dapat disajikan sebagai berikut:

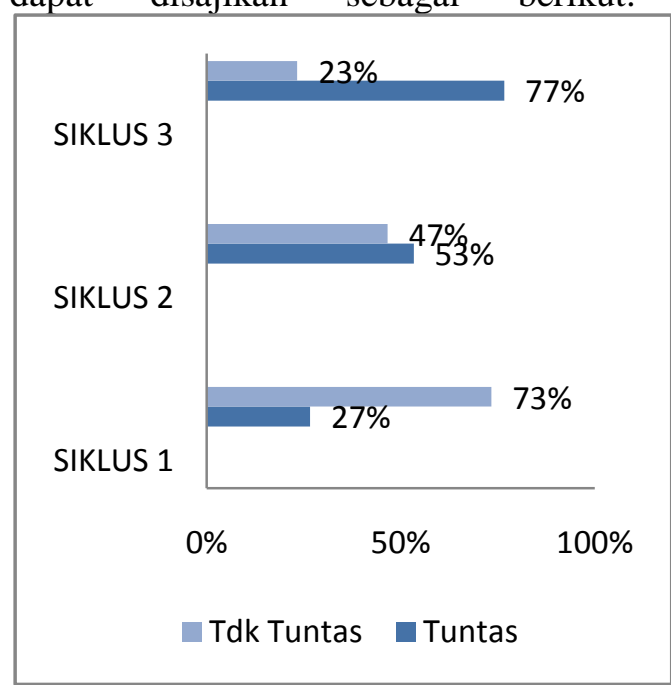

Gambar 2. Grafik Rekapitulasi Hasil Evaluasi pada Masing-masing Siklus
Dari hasil rekapitulasi prosentase ketuntasan belajar mahasiswa pada materi terminologi teori graf di atas, dapat diketahui bahwa terjadi peningkatan ketuntasan mahasiswa dalam hasil evaluasi belajarnya. Hal ini mengindikasikan bahwa pada setiap siklus, mahasiswa mengalami peningkatan pemahaman terhadap materi, sehingga mereka dapat menyelesaikan soal tes yang diberikan oleh dosen dengan baik. Namun hal ini perlu menjadi penelitian lebih lanjut guna menelusuri perkembangan peningkatan aktivitas belajar mahasiswa, khususnya terhadap mata kuliah teori graf.

Terlepas dari hal tersebut, tentu saja beberapa upaya yang telah dilakukan oleh dosen juga memberikan pengaruh yang baik terhadap pemahaman materi oleh mahasiswa pada setiap siklus apabila dibandingkan dengan siklus sebelumnya. Upaya-upaya tersebut diantaranya: pembelajaran dengan model berkelompok, pemberian tugas secara terbimbing dan tugas terbimbing secara individu untuk langsung mengaplikasikan hasil diskusi secara individu di depan kelas dan tidak tergantung atau terpengaruh hasil jawaban antar individu yang lain.

\section{SIMPULAN DAN SARAN}

\section{Simpulan}

Berdasarkan hasil penelitian yang telah dikemukakan di bab IV serta mengacu pada perumusan masalah di depan, maka dapat disimpulkan bahwa: 1) Pemilihan model pembelajaran yang tepat ternyata mampu meningkatkan motivasi dan prestasi belajar mahasiswa. Hal tersebut dapat dilihat dari kegiatan pembelajaran yang dilakukan peneliti pada setiap siklusnya ternyata mampu meningkatkan antusiasme belajar mahasiswa secara mandiri. 2) Model pembelajaran yang berorientasi pada keaktivan, ternyata mampu meningkatkan motivasi dan prestasi belajar mahasiswa. Hal itu terlihat dari 
peningkatan ketuntasan belajar mahasiswa pada setiap siklusnya.

\section{Saran}

Berdasarkan kesimpulan di atas dapat disampaikan beberapa saran berikut :

Kepada Dosen

Dosen hendaknya mampu memilih model pembelajaran yang lebih berorientasi pada keterlibatan langsung mahasiswa dalam kegiatan pembelajarannya. Adapun salah satu contohnya yaitu kegiatan yang berorientasi pada keaktivan mahasiswa mampu meningkatkan motivasi mahasiswa, misalnya dengan menugaskan mahasiswa secara langsung di depan kelas untuk mengaplikasikan teori-teori yang diajarkan. Dosen hendaknya mampu mengoptimal dalam menggali potensi diri mahasiswa yang tidak tampak sehingga akan memiliki motivasi diri dalam pribadinya yang akan terlihat dalam individu yang berbeda.

\section{Kepada Mahasiswa}

Mahasiswa diharapkan senantiasa lebih termotivasi dalam belajar dan serius dalam mengikuti perkuliahan agar lebih mudah dalam memahami materi yang disampaikan oleh dosen.

Mahasiswa hendaknya belajar untuk lebih mandiri dan mampu memanfaatkan waktu berdiskusi belajar secara diri sendiri maupun bersama orang lain.

Keterbatasan Penelitian

Berdasarkan hasil analisa data dalam penerapan pembelajaran menggunakan lembar praktikum terbimbing masih sangat jauh dari sempurna maka penerapan perlu diuji cobakan pada kelas yang lain dan membutuhkan penyesuaian ketercapaian indikator terutama masih banyak mahasiswa yang kurang teliti dalam mengerjakan soal dan memahami perintah yang akan dikerjakan, disarankan untuk lebih memperhatikan hal-hal tersebut.

\section{DAFTAR PUSTAKA}

Afifudin. 1986. Psikologi Pendidikan Anak Usia SD. Solo : Masa Solo

Azhar Arsyad. 2002. Media Pembelajaran. Jakarta: Raja Grafindo Persada

\begin{tabular}{l}
$2004 . \quad$ Media \\
\hline $\begin{array}{l}\text { Pembelajaran. Jakarta: Raja } \\
\text { Grafindo Persada }\end{array}$
\end{tabular}

Arief S. Sadiman, dkk. 2003. Media Pendidikan : Pengertian, Pengembangan, dan Pemanfaatan. Jakarta: PT RajaGrafindo Persada.

Conny Semiawan. 1999. Perkembangan dan Belajar Peserta Didik. Jakarta : Depdikbud.

Hendrikus Midun. 2008. Evaluasi Dan Penelitian Media. Disajikan di http://unesa.info/tep/media/isi.p hp?autor=midun. Diunduh tanggal 21 Maret 2012.

Herman Hudoyo. 1998. Strategi Mengajar Belajar Matematika. Malang: IKIP Malang

Lukman Rosadi, Handani Dadan. 2000. Pendidikan Matematika I. Jakarta: Departemen Agama RI.

Muhammad Fajri. 2009. Seberapa Pentingkah Penggunaan Media Pembelajaran Di Sekolah Dasar. Disajikan di http://vhajrie27.wordpress.com/ 2009/10/08/seberapapentingkah-penggunaan-mediapembelajaran-di-sekolah-dasar21. Diunduh tanggal 21 Maret 2012.

Mulyono

Abdulrahman.1999.

Pendidikan bagi Anak

Berkesulitan Belajar. Jakarta:

Rineka Cipta.

Ngalim Purwanto. 1997. Psikologi Pendidikan. Jakarta: Rosdakarya.

Purwanto. 2004. Pengembangan Multimedia Pembelajaran. Makalah disampaikan dalam Lokakarya Pengembangan Media yang Diselenggarakan 
oleh Jurusan Pendidikan Matematika FMIPA UNY.

Romi Satria Wahono. 2006. Aspek Dan Kriteria Penilaian Media Pembelajaran. Disajikan di http://romisatriawahono.net/20 06/06/21/aspek-dan-kriteriapenilaian-mediapembelajaran/. Diunduh tanggal 24 Maret 2012.

Sagala. 2006. Strategi Pembelajaran. Jakarta: Dirjendikti Depdiknas.

Syaiful Bahri Djamarah. 2002. Psikologi Belajar. Jakarta: Rineka Cipta.

Slameto.1995.Proses Belajar Mengajar Dalam Sistem Kredit. Jakarta: PT Bumi Aksara.

Soli Abimanyu. 2008. Strategi Pembelajaran. Jakarta: Dirjen dikti Depdiknas.

Sri Rumini.1995 Psikologi Pendidikan. Yogyakarta: UPP IKIP yogysakarta.
Suharsimi Arikunto. 1998. Prosedur Penelitian Suatu Pendekatan Praktik. Jakarta : PT Rineka Cipta.

Suhito.2001. Hand Out Dasar-dasar dan Proses Pembelajaran matematika I. Semarang: FM IPA UNES.

Suryo, DTM. 1996. Pengantar Bimbingan dan Penyuluhan. Jakarta: Universitas Terbuka.

Syukri.2009. Panduan PTK. Jakarta : Dirjen dikti Depdiknas.

Umar Hamalik. 1989. Metodologi Pengajaran IImu Pendidikan. Bandung: Mandar Maju

Winarno, dkk. 2009. Teknik Evaluasi Multimedia Pembelajaran. Genius Prima Media.

Yudhi Munadi. 2008. Media Pembelajaran: Sebuah Pendekatan Baru. Jakarta: Gaung Persada Press

Yusuf Hadi Miarso. 2005. Menyemai Benih Teknologi Pendidikan. Jakarta: Prenada Media. 